\title{
A RECORD OF A BIFID ROSTRUM IN THE PENAEID SHRIMP PARAPENAEOPSIS HARDWICKII (MIERS, 1878) (DECAPODA, PENAEIDAE) FROM PALK BAY, TAMIL NADU, INDIA
}

BY

\author{
MUTHUSAMY RAJKUMAR ${ }^{1,3}$ ), RAJU SARAVANAN ${ }^{1}$ ), GIDDA MAHESWARUDU ${ }^{2}$ ) \\ and ABDUL KUTHOOS ABDUL NAZAR ${ }^{1}$ ) \\ 1) ICAR-Central Marine Fisheries Research Institute, Mandapam Regional Centre, \\ Mandapam Camp, Tamil Nadu, India-623520 \\ 2 ) ICAR-Central Marine Fisheries Research Institute, Kochi, Kerala, India-682018
}

\section{INTRODUCTION}

Abnormal changes in the morphology of the appendages and body segments in decapods crustacean have long been noticed in the wild (Fauvel, 1900), including duplication of structures (Rudolph, 1996; Nakatani et al., 1997), lack of such structures (Kulkarni et al., 1980), reversal of asymmetry (Stevens \& Munk, 1991) and deformed sexual appendages (Rodriguez \& Campos, 2000). In shrimps, abnormalities of the rostrum have often been reported (De Grave, 1999) and mostly deal with a significant increase in size of the rostrum or in rostral teeth number (Ayub \& Ahmed, 1991). Variations in the rostral shape, teeth number or shape and length have been further noticed in several species, e.g., Penaeus penicillatus Alcock, 1905, Penaeus merguiensis De Man, 1888 and Metapenaeus affinis (H. Milne Edwards, 1837) (Ayub \& Ahmed, 1991). The present study report the rostral deformity in Parapenaeopsis hardwickii for the first time from Palk Bay.

\section{MATERIAL AND METHODS}

During routine analysis of the catch in shrimp trawl at Rameshwaram landing centre, Palk Bay coast of Tamil Nadu, India on 16 June 2016, specimens of Parapenaeopsis hardwickii (Miers, 1878) were separated for closer examination. Among these a female of $P$. hardwickii was unusual in shape, with a bifurcated rostrum. Deformity in shrimps has been reported in many species, but to our

\footnotetext{
3 ) Corresponding author; e-mail: rajfcri@gmail.com 
knowledge for this species of shrimp such a deformity has never been documented. The species was identified using FAO species identification sheets, fishing area 51 (Fischer \& Bianchi, 1984). All the morphometric measurements were taken to the nearest $1 \mathrm{~mm}$ with digital Vernier calliper (Mitutoyo CD-6CSX); the weight was measured to $0.1 \mathrm{mg}$ accuracy (Shimadzu AY 220). The deformed specimen has been deposited with the Marine Biodiversity Museum of Central Marine Fisheries Research Institute, Mandapam with the accession number CMFRI-AR-346.

\section{RESULTS}

The total length of the abnormal female shrimp is $113 \mathrm{~mm}$, the carapace length $42 \mathrm{~mm}$ and the total body weight is $11.1586 \mathrm{~g}$ (fig. 1). The length of the rostrum is $14 \mathrm{~mm}$, with a lateral bifurcation starting at about two-thirds (10 mm) of the rostrum length, the length of the right and left prong is 3 and $4 \mathrm{~mm}$ and the prongs' inner angle is ca. $74^{\circ}$ (fig. 2). In addition to the bifid tip, the rostrum is also deflexed to the right and the upper carina looks twisty and maybe engrossed at its base. The rostrum length/carapace length was analysed for both normal and abnormal specimen of $P$. hardwickii and it was found that the ratio was 0.46 and 0.23 for normal and abnormal specimens, respectively. In normal specimens of $P$. hardwickii, the rostrum is armed with 8-10 dorsal teeth, including post-rostral teeth. Whereas, the abnormal specimen possessed two post-rostral dorsal teeth, and the distal, bifurcate portion of the rostrum was smooth. In both normal and abnormal specimens, the thelycum features a concave anterior plate, rounded anteriorly and a posterior plate flat with a pair of anterolateral tooth-like projections. The abnormal female was found to be fully matured and the gonad was fully greenish in colour, which extending to the last abdominal segment.

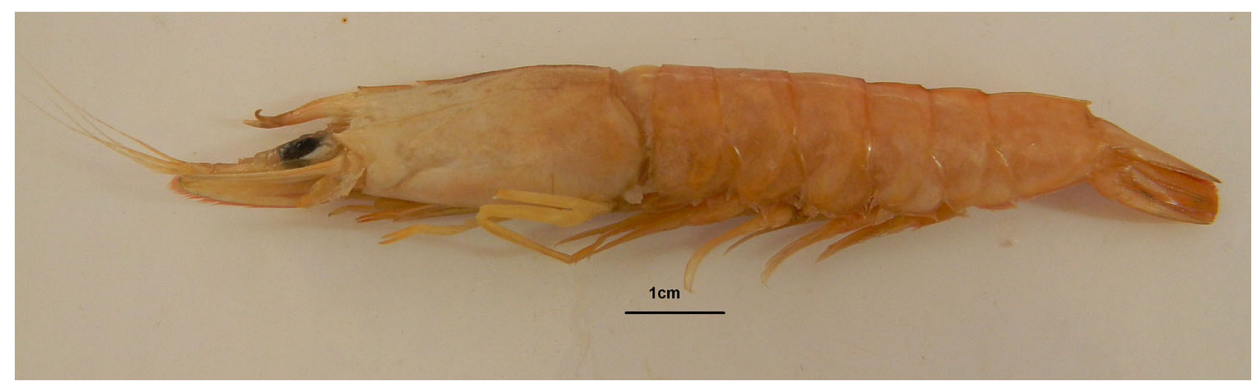

Fig. 1. Lateral view of the abnormal specimen (formalin preserved) of Parapenaeopsis hardwickii (Miers, 1878). This figure is published in colour in the online edition of this journal, which can be accessed via http://booksandjournals.brillonline.com/content/journals/15685403. 


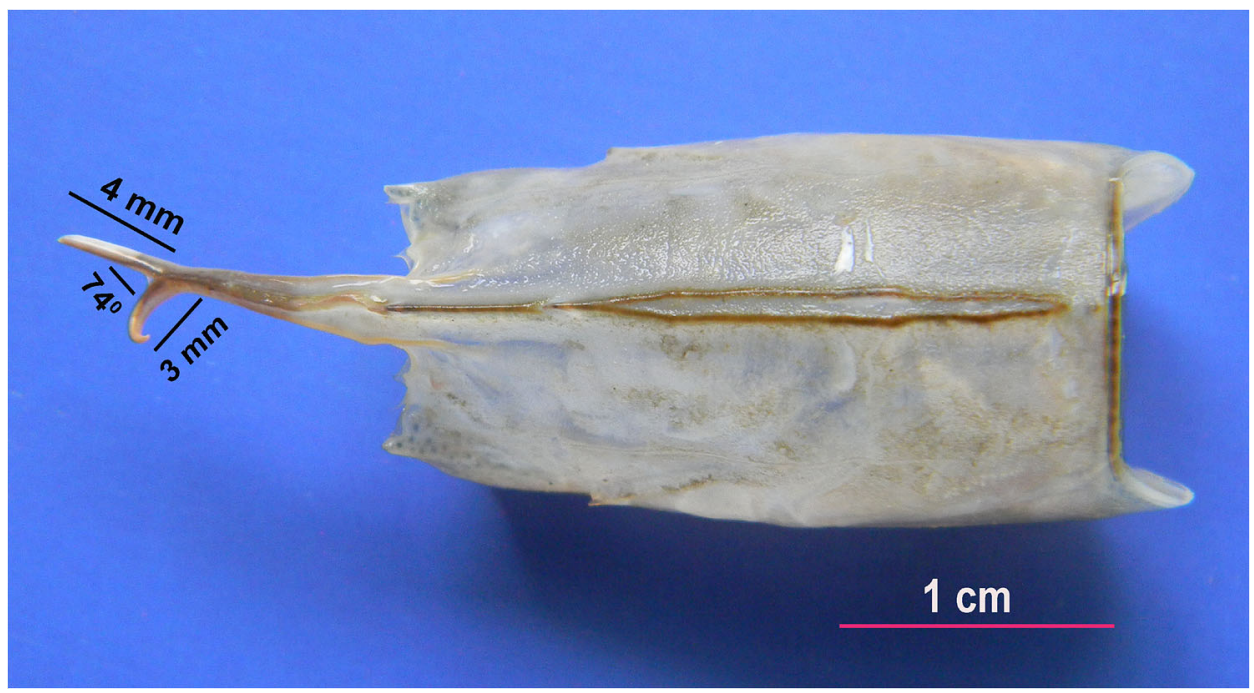

Fig. 2. Abnormalities in the rostrum of the Parapenaeopsis hardwickii (Miers, 1878). This figure is published in colour in the online edition of this journal, which can be accessed via http:// booksandjournals.brillonline.com/content/journals/15685403.

\section{DISCUSSION}

Rostrum bifurcation in decapods has been reported by various workers (Fauvel, 1900; Aguirre \& Hendrickx, 2005; De Grave \& Mentlak, 2008); however, such deformity appears to be a relatively rare phenomenon in shrimp populations in the wild. Morphological variations in rostral structure and size during growth have been reported as a normal ontogenic occurrence (Hendrickx et al., 1998; De Grave, 1999). In penaeids the rostrum size, length and dentition appear to be much more stable than in carideans shrimps, both in regard to shape and relative length. Fauvel (1900) reported a case of a bifid rostrum in Palaemon serratus (Pennant, 1777) and in that specimen the normal rostrum was conserved and a second, accessory rostrum emerged at its left base at an angle of $45^{\circ}$, whereas in the present specimen the angle was recorded more than this, with a lateral bifurcation at about two-thirds of the rostrum. In the present study, the value of the ratios between rostrum length and carapace length was recorded to be lower for the deformed shrimp than the normal shrimp.

There is an intensive shrimp fishery in the region of Palk Bay, particularly in shallow water, since 1960. Parapenaeopsis hardwickii comes in trawl nets as a by-catch species along with the target shrimp fishery for Penaeus semisulcatus De Haan, 1844 and Penaeus latisulcatus Kishinouye, 1896. Based on the continuous observations of the shrimp landing at Rameshwaram landing centre for an about two-year period and the absence of any industrial activity along the Palk 
Bay coast, it is suggested that environmental pollution may not be the sole reason for this deformity in this instance. Furthermore, no information could be collected on contamination levels in the ecosystems where the shrimp was caught. While analysing various reasons for the deformity in the P. hardwickii, three hypotheses were drawn. The specimen examined showed no sign of external parasitic infections, so the possibility of a parasite interaction is not retained. However, Palk Bay, which is dotted with more than 70 shrimp farms along its coast (Anon, 2014), releases huge quantities of high organic load waste-water into the Palk Bay ecosystem directly without any treatment. Such discharge of effluents could be one of the reasons for such deformity in the wild population of $P$. hardwickii. This second hypothesis is based on the earlier observation of Béguer et al. (2008), on Palaemon longirostris $\mathrm{H}$. Milne-Edwards, 1837, where a high organic load in the ecosystem could cause such mutation in the wild population. During our two years of surveying shrimps along this coast, only a single case of rostral deformity has been observed; hence it will be a premature speculation to conclude on the pollution aspect. Third, the rostral deformity could have been due to poor wound healing as reported by Shelton et al. (1981). This is quite acceptable in the present case, hence, it is concluded that the third hypothesis of poor wound healing after moulting may be a possible reason for such deformity in P. hardwickii along this coast. Further studies on the organic load and disease surveillance in Palk Bay would provide more insight into the deformity of crustaceans in general along this coast.

\section{ACKNOWLEDGEMENT}

We are grateful to the Director, Central Marine Fisheries Research Institute, Kochi for the kind support in the execution of this work.

\section{REFERENCES}

Aguirre, H. \& M. E. Hendrickx, 2005. Abnormal rostrum and telson in two species of penaeid shrimp (Decapoda, Dendrobranchiata, Penaeidae) from the Pacific coast of Mexico. Crustaceana, 78: 113-119.

ANON, 2014. Annual report, Coastal aquaculture authority. (Ikon Print Solutions, Chennai).

Ayub, Z. \& M. Ahmed, 1991. Rostral variations in the shrimps Penaeus penicillatus, P. merguiensis and Metapenaeus affinis from Pakistan. Pakistan J. Zool., 23: 185-186.

BÉguer, M., S. PASquAud, P. NoËL, M. GIRARdin \& P. BoËT, 2008. First description of heavy skeletal deformations in Palaemon shrimp populations of European estuaries: the case of the Gironde (France). Hydrobiologia, 607: 225-229.

DE GRAVE, S., 1999. Variation in rostral dentition and telson setation in a salt marsh population of Palaemonetes varians (Leach) (Crustacea: Decapoda: Palaemonidae). Hydrobiologia, 397: 101-108. 
De Grave, S. \& T. Mentlak, 2008. A record of an unusual rostrum in Palaemon longirostris H. Milne-Edwards (Decapoda, Palaemonidae). Crustaceana, 81: 1403-1406.

Fauvel, P., 1900. Palaemon serratus Penn. à rostre monstrueux. Feuille Jeunes Nat. Paris, 359: $2 \mathrm{pp}$.

FISCHER, W. \& G. BIANCHI, 1984. FAO species identification sheets for fishery purposes. Western Indian Ocean (Fishing Area 51). Prepared and printed with the support of the Danish International Development Agency (DANIDA), Vol. 5. (Food and Agricultural Organization of the United Nations, Rome).

Hendrickx, M. E., F. Osuna-Paez \& H. M. Zazueta-Padilla, 1998. Biology and biochemical composition of the deep water shrimp Heterocarpus vicarius (Crustacea: Decapoda: Caridea: Pandalidae) from the south eastern Gulf of California, Mexico. Bull. Mar. Sci., 63: 265-275.

Kulkarni, G. K., R. Nagabhushanam \& P. K. Joshi, 1980. An unusual abnormality in the development of an eye of a marine penaeid prawn, Parapenaeopsis stylifera (H. Milne Edwards) (Crustacea, Decapoda, Penaeidae). Hydrobiologia, 74: 283-284.

NaKatani, I., Y. OKadA \& T. Yamaguchi, 1997. An extra claw on the first and on the third cheliped of the crayfish, Procambarus clarkii (Decapoda, Cambaridae). Crustaceana, 70: 788798.

Rodriguez, G. \& M. R. CAMPOS, 2000. Microthelphus asucreensis, a new species of Pseudothelphusidae (Decapoda), with notes on abnormalities in the sexual appendages of fresh-water crabs. J. Crust. Biol., 20(Suppl.): 332-336.

Rudolph, E., 1996. A case of teratology in Parastacus nicoleti (Philippi, 1882) (Decapoda: Parastacidae). Gayana Zool., 60: 13-16.

Shelton, P. M. J., P. R. Truby \& R. G. J. Shelton, 1981. Naturally occurring abnormalities in the chelae of three species of Crustacea (Decapoda) and a possible explanation. J. Embryol. Exp. Morphol., 63: 285-304.

SteVens, B. G. \& J. E. MunK, 1991. Lateral asymmetry in the thoracic segmentation of a king crab, Paralithodes camtschaticus (Tilesius, 1815) (Decapoda, Anomura), from Kodiak, Alaska. Crustaceana, 61: 317-319.

First received 1 July 2016.

Final version accepted 16 September 2016. 